\title{
Gender Formation of Foster Children at Aisyiyah Female Orphanage of Tegal Municipality Based on Muhammadiyah Gender Ideology
}

Komunitas: International Journal of Indonesian Society and Culture 10(1) (2018): 147-156

DOl:10.15294/komunitas.v9i1.7272 (C) 2018 Semarang State University, Indonesia p-ISSN 2086 - 5465 | e-ISSN 2460-7320 http://journal.unnes.ac.id/nju/index.php/komunitas

UNNES JOURNALS

\section{Yuni Zaharani ${ }^{1}$, Elly Malihah ${ }^{2}$, Siti Komariah ${ }^{3}$, Siti Nurbayani ${ }^{4}$}

1,2,3,4 Department of Sociology Education, Graduate School, Indonesia University of Education

Received: 20 September 2016; Accepted: 20 October 2017; Published: 30 March 2018

\begin{abstract}
Gender, together with all problems that it brings, becomes a discourse discussed in various countries, not excluding Indonesia. The Indonesian government through its policy keeps on creating gender equality and justice. The effort of government needs supports from all society elements, including orphanage. An orphanage needs to try to minimize and omit gender stereotype because the continuation of family informal socialization occurs here and it nurtures many children at the same times. The aim of this article is to analyse and describe children formation gender role at Putri Aisyiyah orphanage, Tegal based on Muhammadiyah gender ideology, whether it still preserves or has minimized and deleted gender stereotype. This research uses qualitative approach with the phenomenology design. The data is obtained by observation, interview, and documentation. The data analysis applies Miles and Huberman models. The formation of gender role at the orphanage is shown by the followings: the formation of gender role is done to form the female children as ideal women according to the orphanage. Ideal women according to the orphanage which is already similar to Muhammadiyah's concept of gender, are those who can take parts in public without space leaving their obligations at home as wives and mothers. Independence, discipline, leadership are imposed to the children at the orphanage to support their roles in public. Feminism and domestic skills are educated to support their roles at homes.
\end{abstract}

\section{Keywords}

foster children; orphanage; gender roles

\section{INTRODUCTION}

Gender equality and justice in Indonesia are still considered low based on Global Gender Gap Report, World Economic Forum, where the country ranks 92nd out of 142 countries. Ten countries are considered have better equality and justice based on Global Gender Gap Report. Those are Iceland, Norway, Finland, Sweden, Ireland, Rwanda, Filipina,
Swiss, Slovenia, and New Island (Webforum Report, 2015).

The gender inequality and injustice were sourced from the stereotype of gender roles within society (Haines, Deaux, \& Lofaro, 2016). Gender stereotype is the labeling

\footnotetext{
Corresponding author

Jl. Dr. Setiabudi 229 Bandung 40154,

West Java, Indonesia

Email

yuniizaharanii@gmail.com; ellyms@upi.edu
} 
toward to one of the gender and declining to be negative and it will cause injustice (Fakih, 1996, hlm. 12), in which men should possess masculinity (rational, strong, manly and other qualities), while women should have femininity (gentle, compassionate, otherhood, others). It is often considered inappropriate where women incline to be masculine and vice versa (Murnen, Greenfield, Younger, \& Boyd, 2015). Masculine and feminine labelling has influenced the roles of men in public sphere and women in domestic realm. In fact, being a woman is not a fate, so it can be shifted. Women may work at public domain, and it is not an exception if men do take part in domestic realm.

It is vitally important for society to take a role seriously to embody gender equality and justice in Indonesia. Starting from government, social organizations, social elements, prominent figures, to families (Marpinjun \& Ramsey, 2017). The Indonesian government has actually been concerned on gender issues, implemented by issuing the Presidential Instruction No. 9 Year 2000 on gender mainstreaming which is followed by other policies on gender issues. Gender mainstreaming is one of strategies to achieve the equality and justice by integrating gender issues into planning process, actuating it, controlling and evaluating policy, program and the national development in all aspects (Mataram, 2016). Government policies cannot give maximum result without support and contribution of all society members. Moreover without minimizing and eliminating gender stereotype which lead to the discrimination and cause inequality and injustice (Chu \& Gruhn, 2017).

The contribution of the orphanage as the social institution in order to achieve gender equality and justice are needed. An orphanage, according to Social Department of the Republic of Indonesia (2004, page 4) is defined as the institution in gaining the social welfare and has responsibilities to provide social services for the homeless children by conducting and protecting them, giving the services as a parental replacement in fulfilling physical, mental, and social needs so they can gain a wider opportunities, better living places, in order for them to be able to improve their personalities and characters as the one who will be the next generation in continuing the goals of the nations and able to contribute in national development. It is a social agent as the parental replacement and a place for nurturing a large number of children at a time, and as an institution which teaches them in minimizing and eliminating gender stereotype (Çatay \& Koloğlugil, 2017).

The orphanage contribution can be conducted by stopping gender stereotyping in the role of nurturing the children themselves (Sherr, Roberts, \& Gandhi, 2017). This means that an orphanage in constructing the role of gender is not focusing solely on feminine stereotype for women and masculine for men as seen in Indonesian culture. It is not appropriate to judge children when their behaviors are not in line with their gender roles.

Putri Aisyiyah orphanage in Tegal is an organization owned and run by Aisyiyah, a women organization established by $\mathrm{Mu}-$ hammadiyah. It has becomes gender ideology of Muhammadiyah as the principle in forming the gender role to the children.

Ideally, to form children gender role at Aisyiyah orphanage, Tegal, does not perpetuate gender stereotype as it bases its principles on Muhammadiyah gender ideology. It is an ideology based on Islamic progressive values, more flexible in viewing the laws/ verses of the Holy Quran/ Hadist whose the interpretation sometimes tends to have gender bias (Nasip, 2017). Muhammadiyah openly and selectively studies the Holy Quran and Hadith by refering to opinion of Salaf/in the past and Khoulf/ in the present (Qodir, 2010, hlm. 102). Islam does not distinguish men and women. The discrimination and gender bias are actually formed by cultural construction (Zumrodizo16, hlm. 271). But missinterpreting the Holy Quran also has the crucial part in understanding the gender concept. This cannot be separated from the tradition of some people in interpreting the Quran partially and comprehensively, while in understanding which emphasizes the textual elements than con- 
textual one (Hamed \& Aziz, 2016).

This study traces how gender construction of foster children at Aisyiyah female orphanage, Tegal, which uses Muhammadiyah gender ideology as the basic principles. Do they still perpetuate gender stereotype or have they been already minimizing and eliminating gender stereotype?

This study is based on the research conducted at Aisyiyah female orphanage, Tegal. The Symbolic interactionism theory is used to describe how agent of gender socialization forms the gender grole at Aisyiyah female orphanage based on Muhammadiyah ideology.

\section{RESEARCH METHOD}

This research uses the quantitative method with phenomenology approach. This approach emphasizes on subjectivities human experiences and the interpretation of the world (Wojnar \& Swanson, 2007) (Moleong, 2010, page.15).

The location of the research is at Aisyiyah female orphanage, Tegal, which is located at Jl. Perintis Kemerde Perintis Kemerdekaan No. 28 Tegal, Central Java. The subject of the research is the key informants (the committee and the foster children) and the supporting information (the leader, committee, employee of the orphanage). The data obtained by interviewing, observation, and documentation are then analyzed by applying Milles and Huberman model. The analysis technique consist of data reduction, and data verification. The data are then validated using the triangulation source and technique.

\section{LITERATURE REVIEW}

Researches on gender in Indonesia which are conducted in the nurturing children are stil in infancy. However, one of the researchers found that gender stereotype still perpetuates in an orphanage. Caregivers nurture male students to be masculine, responsible, aggressive, firm, independent, tough mentally or physically, active, able to protect, smart, self-reliance, and showing good lea- dership. Meanwhile, women should be feminine, respectful, able to behave politely, gentle, able to help the mother, polite, patience, motherly, pleasing, and polite. Men with their masculinity are demanded to take the roles in public area and the women with their femininity are demanded to take the roles in domestic realm (Suteja, 2013).

How is the formation of gender role at Aisyiyah female orphanage, Tegal, which is based on Muhammadiyah gender ideology, conducted? Do they still use the gender stereotype, the same case with gender socialization at Lembaga Pengasuhan Sos Children's Village Lembang, West Java, or have they tried to eliminate and minimize gender stereotype? We will find the result in this research.

In order to reveal what gender roles have been internalized to children, it is important to describe the ideal figure of women at Aisyiyah female orphanage, Tegal. The ideal women in the orphanage is determined by Muhammadiyah gender ideology. It is influenced by the gender construction in Muhammadiyah social neighborhood. At that time, gender construction refered to Netherland and Javanese nobility (Dzuhayatin, 2015). Gender construction can be seen in the pattern of the family system in the colonialism era and Javanese social system.

Gender construction in Javanese nobility (priyayi) society influences gender construction in Muhammadiyah society because in the beginning of their development, the majority of organization members came from Kauman area of Yogyakarta: a priyayi-santri based society. The gender construction in priyayi society was divided into two: traditional and modern. The husband-wife relationship pattern in the gender construction of traditional priyayi was Owner Property (husband as the owner/ruler of the family). This relationship pattern was marked by hierarchical asymmetric status between husband and wife, in which husband and father performed as owners and ruler of family can treat their wives and children according to their will. Husbands were the absolute determinant of fami- 
ly status accumulatively, while father had the right to marry their children as a way to exchange their interests of power (Retsikas, 2016). Husband-wife relationship pattern that was dominated by husband/men can be found among traditional priyayi society, especially the society of Javanese palace (kraton). The family form of owner property relationship pattern tended to be polygamist (Izharuddin, 2017). A good example for this case was King Paku Buwono IX who had two wives and fifty one mistress. Polygamy became a symbol of male power in traditional priyayi society at this era. The forming of Owner Property relationship pattern cannot be separated from the cosmology of Javanese culture about women. Javanese proverbs, such as Kanca Wingking; Swarga Nunut Neraka Katut; and Macak, Masak, Manak; reflect the ideal figure of a woman according to Javanese culture. Kanca Wingking, which literally means a friend at the back, implies that a woman is a friend who always stands behind her man/husband. Swarga Nunut Neraka Katut means a woman will follow you to heaven, but she will also follow you even to hell. In other words, a woman's life in the world and the hereafter depends on the world's mercy from the husband and the hereafter's mercy from Allah.

Recently, Owner Property relationship pattern in traditional priyayi family has shifted into Head Complement relationship pattern (a wife is a complement for her husband). This situation goes along with the development of priyayi society that is initially traditional to be more modern. This modern priyayi relationship pattern is influenced by the gender construction from the Dutch colonial government. Other important things that affect this condition is education, which could be accessed by women such as Kartini, and monogamous conjugal family form in Dutch family which was then adopted by modern priyayi family (Efferin, Frisko, \& Hartanto, 2016). Even though female education in colonial era was limited and oriented in women's affairs such as cooking, sewing, and embroidering, it was still successful to make women possess knowledge and skill (Efferin et al, 2016). It has changed the ima- ge of women as passive subject (in Owner Property relationship pattern) into more active subject (in Head Complement relationship pattern). Head Complement relationship pattern gives a role for wives to solve problems in family. Husband is no longer seen as the owner of family, but as the head of family and the decision maker in family. In a more detailed term, Head Complement relationship pattern is marked by hierarchical asymmetric status of husband and wife, in which husband serves as the head of family, the determinant of family status, the breadwinner, and the decision maker; while wife has secondary role in family as an educator for children and the decision maker for internal affairs (Riany, Meredith, \& Cuskelly, 2016).

In its development, head complement relationship pattern has shifted into Senior Junior Complement pattern. This pattern is marked by relative asymmetric status between husband and wife: they are comradein-arms, where husband takes a role as the head of family, the determinant of family status, the breadwinner, but not the one and only decision maker, while the wife takes part in the decision-making process, participate in social and public activity, but not as wage earner (Bogaerts, 2017). Senior Junior Complement relationship pattern can be seen in the relationship between R.A. Kartini and her husband. Kartini saw her husband not merely as the head of family but also as a comrade-in-arms. In this pattern, women do not have economic function and have main role as housewife, whereas husband is the head of family and the breadwinner.

Senior Junior Complement relationship pattern in R.A. Kartini's family had inspired K.H. Ahmad Dahlan to apply the more modern pattern, theSenior Junior Partnership, with his wife, Nyai Ahmad Dahlan/Siti Walidah. Ahmad Dahlan imitated the figure of Aisyah, the wife of Prophet Muhammad PBUH, as an active woman, a hadith narrator, a teacher for Moslems, worked to fulfill the needs of her family, and involved in political matters (Miftachul Huda \& Kartanegara, 2015). Through Muhamma- 
diyah organization, Ahmad Dahlan actively improved women's status. He encouraged young women to achieve the highest level education just like men. He also encouraged young women to ride bicycle so that it would be easier for them to gain more knowledge. Ahmad Dahlan's effort to upgrade women at that time was controversial and opposed by other theologians (Al-anshori, 2016). Senior junior partnership relationship pattern was also applied in the people in Kauman Yogyakarta widely.

Senior junior partnership relationship pattern in Ahmad Dahlan's family and Kauman Yogyakarta society then become the basis for Muhammadiyah's gender ideology and it lasts until now. Senior junior partnership relationship pattern is marked by relative symmetrical status between husband and wife: they are comrade-in-arms, the husband is the head of family, the determinant of family status, they both earn money together, they make decision by discussing the matter first, and both of them have social activity (Riany et al., 2016).

Finally, Muhammadiyah's gender ideology stops in this senior junior partnership relationship pattern since it still strongly believe in the ideal leadership according to Islamic teaching; men are the spiritual leader (the imam) and the head of family. Based on this belief, men have higher position than women. The Imam is the leader in pyaying (shalah), whereas the head of family is the leader in the family (Shah, 2010). This concept of Imam and the head of family is not only applied in men leadership in family, but also in the wider aspect of life (Aryanti, 2013).

In its practice, the husband and wife relationship in Muhammadiyah's family is not only limited in senior junior partnership, but is also affected by head complement relationship pattern. Head complement relationship pattern affirms the role as husband as the breadwinner and the head of family, whereas wife has a role as the manager of the house and the housekeeper (Fuad, 2004). Based on this explanation, it can be understood that Muhammadiyah's gender ideology is based on senior junior partnership relationship pattern, which in its practice is affected by head complement relationship pattern. Senior junior partnership pattern supports female to earn extra income and have social activity even though the head of the family is the husband. On the other side, head complement pattern decisively place women as the manager of the household and men as the breadwinner.

\section{FINDINGS}

Ideal woman according to the gender ideology of Muhammadiyah has been used by the Putri Aisyiyah orphanage of Tegal Municipality to form ideal gender roles on female foster children. Ideal women's roles are, therefore, those who perform their public roles as well as household obligations.

In order to support gender role socialization of foster children in the public space, the orphanage encourages such masculinerelated values as independence, discipline, and leadership. On the other hand, to support household roles, domestic skills and femininity are instilled.

The femininity is instilled in foster children in order for them to be good wives and mothers in the future. Instilling femininity in children means imposing such values as motherhood, love, gentleness, patience, and emphaty to them. This process is carried out by applying several methods. First is through provision and choice of attire for children. The orphanage facilitates them by providing school uniforms and clothes for the Eid holiday, while for daily clothing they bring their own or were provided by donors.

For Eid festivity, the clothing chosen by the orphanage should cover all body parts that are required by Islamic teachings. These clothings were chosen that women should keep to cover their body as taught by religion, be polite, graceful, and keep themselves from men. As for the choice of color for clothing, the orphanage has chosen appropriate color for girls such as pink, orange, light green, and violet. These colors were chosen to reflect values that women are faminine, gentle, warm, nice and cheerful. Inaddition, clothing colors were also com- 
bined appropriately as in orange clothes were fitted with darker orange veil, which implies that women should dress up neatly and appropriately.

Second method is by imposing such advise by the guardians to the foster children as respecting the elders, love, and care for the people. They were also taught to be more open minded by telling others experience and problems they were currently facing. This has made relations among children so close as they stayed in the same place for a long period of time. Furthermore, their ages were also similar. Openness among children has made them be able to help each other every time their friends were in a trouble.

Third method through extracurricular activities provided for the children. These activities available for them were sewing, handcrafting, making cakes, choir, rebana, memorizing the Holy Quran, and martial arts. For these activities, children were allowed to choose based on their interests, and the orphanage management invited instructors for these extracurricular activities.

The extracurricular activities for foster children were those which were closely related with femininity, such as sewing, handcrafting, and making bakery and cake. These three activities require patience and precision, which is considered part of womanhood. The Tapak Suci martial art had been the only activity closely related with masculinity. Martial art is taught to children in order for them to be able to defend themselves from harassment and violence. However, it was no longer at the orphanage since children's participatio in its activities was low.

Fourth is by the choice of school department associated with femininity. The orphanage gave freedom for the children to decide to which schools they wished to continue their education. It did not force them to go to a high school or a vocational one, in which choices of departments were by children themselves whether to choose natural science department or social science department at a high school, or the department of electricity, automotive, multimedia, fashion, culinary, hospitality, or skin and hair health at a vocationa school. However, though children had their right to choose their schools, guardians still described what department may be suitable for them, based on thei interests. The orphanage advised children to choose such femininity-related departments as multimedia, culinary, hospitality, and hair and skin treatment.

Fifth method is by domestic skills. The orphanage instilled children the domestic skills to prepare them as wives and mothers in the future. These skills were given through daily works, which were obilgation for each child, including floor sweeping and mopping, cleaning bathroms and bedrooms, and cooking.

Floor sweeping and mopping were carried out twice a day in the morning and late in th afternoon. During the daiy work, all children should involve, and were divided into small groups consisting of 3 to 4 children to sweep and mop parts of the building such as guest room, office, bed rooms, study rooms, dining rooms, kitchen, prayer room, yards, and so forth. This duty was based on age of children, in which younger children usually did lighter works. Unlike scheduled sweeping and mopping duties, cleaning bathrooms and bedrooms were not scheduled more than once a day. Cooking was also carried out once a day, namely at the afternoon to prepare for dinner but it was also flexible according to children's activities at a particualr day.

Children who disobeyed the rules and regulations would be sanctioned, based on types of disobedience in the forms of cleaning the orphanage area determined by the teachers or memorizing the Holy Quran. If it was a serius disobedience, their daily pocket money will be cut or they will have to face official school trial and be dropped out from the orphanage.

Imposing independence at Aisyiyah Putri orphanage in Tegal Municipality is carried out by insisting habitual activities in the forms of doing daily routines by themselves. For example, children should perform their daily routines such as waking up early, praying, doing dily work, attending classes, and going to bed in a disciplined manner. Additionally, they also have personal res- 
ponsibilities besides daily works, i.e. washing their dish, washing and ironing their own clothings, and tiding up their personal belongings. Though these routines were not scheduled, the guardians would make an unplanned inspection to children's rooms on certain times to ensure their room condition, clothing wardrobe, books, and other equipment. Those children whose rooms were dirty would be advised and sanctioned. In addition to giving them tasks, foster children were also given formal (school) and non-formal education, such as sewing course, handcrafting, and cake making to support their future career.

Discipline was imposed by arranging daily activities though a tight schedule, and they were also given books containing daily assesment forms. This assesment was catogorixed into three different religious activities, namely daily prayer, night prayer, unobligatory prayer, unobligatory fasting, memorizing the Holy Quran, and memorizing daily prayers. Meanwhile, daily routines include morning wake up, personal cleanliness, proper clothing, studying, and resting/sleeping), and soft skills category include greetings, smiling, politeness, caring, cleanliness, discipline, achievement, courage, and creativity. The assessment was based on scales ranging from $\mathrm{A}, \mathrm{A}-, \mathrm{B}, \mathrm{B}-, \mathrm{C}$, and $C-$, which would be summarized as a benchmark for assessing children's discipline and behavior.

As for imposing leadership, the first thing the orphanage did was to make sure that leadership was instilled in the chldren to build their confidence. Foster children who were from impoverised families would be given treatment to improve their confidence by continuosly motivating and assisting them by the guardians and other socialization agents in the orphanage. In addition, there are values that are instilled in these foster children that they are equal to other children outside the orphanage, where they have the same opportunities, abilities, and potential to be a good person, gain achievement and a bright future. In religious terms, there are values given to them that nothing is impossible if God has His will. After foste- ring self-confidence, the orphanage also imposed freedom to foster children to express their opinions. For example, foster children were involved in making daily work and daily activity schedules. It also provides a suggestion box that accommodates suggestions and complaints related to orphanage services.

In addition, there is another way that the orphanage made, namely by conducting training for children to become leaders by giving responsibilities to some foster children to become chairpersons of the rooms, where each room had one room chairman. The head of the room was chosen by the room members themselves by requesting consideration and approval from the caregiver. The criteria for selecting a chair is based on the character and personality of foster children. Those who can manage themselves and protect their friends will be elected as leaders. Meanwhile, the task of chairing the room is to ensure the condition of the room is clean and tidy, to help roommates who are in trouble, to help communicate the problem with the caregiver, and so forth. They were also involved in certain events such as the anniversary celebration of the orphanage, where one or two foster children were chosen to be the chairman who coordinated his friends to form a committee. The foster committee would help caregivers and other guardians to succeed in celebrating the orphanage's anniversary.

The formation of gender roles of foster children in the Putri Aisyiyah orphanage in Tegal Municipality has promoted women's roles, even though they have not achieved gender equality as formulated by Western feminists (liberal / radical). The formation of gender roles of foster children is based on the Muhammadiyah's gender ideology, which was based on the teachings and values of the Islamic religion derived from the Holy Qur'an and the Hadith.

\section{DISCUSSION}

Based on the findings described above, it is clear that from the point of view of Western feminist gender ideology, the formation of 
gender roles of foster children in the Putri Aisyiyah orphanage in Tegal Municipality still perpetuates gender stereotypes. This can be seen in the ideal figure of women (foster children) who may take part in the public domain, without leaving their obligations in the domestic realm. However, when viewed from the perspective of Muhammadiyah's gender ideology, the formation of gender roles of foster children in the Aisyiyah orphanage in Tegal has shown the progress of women's roles in accordance with the teachings of Islam. This is evidenced by the permissibility and support of women's work in the public sphere without leaving their obligations as a wife and a mother.

The concept of the Muhammadiyah's gender ideology actually still maintains the concept of the Senior-Junior Partnership, where they selectively accept the development of feminist discourse. However, family leadership is still associated with men, even though now this position has undergone many changes, which consider that husband and wife can share household duties, with the function of the head of the family remaining in men with normative justification for male as a prayer leader (Dzuhayatin, 2015). This is an effort to raise awareness that access to education and the economy may depend on the wife's own will (Atmadja, Sendratari, \& Rai, 2015). Husbands do not advise women to work in the public domain. Instead, they support what their wives do for family progress (Tong, 2007).

Imposing Muhammadiyah feminist values conducted at the Aisiyah orphanage in order to realize the gender ideology of Muhammadiyah is seen in the five basic education that are accustomed to the daily lives of students, starting from the selection of clothes to the selection of jobs performed inside the orphanage. Uniquely, however, children are free to choose which school to choose (high school or vocational high school). Freeing these choices has provided opportunities for students to take part, both domestically and publicly. It is also a manifestation of a Psychoanalytic Feminist in which masculinity and femininity are only psychic with interdependent relationships
(Bowman, 2016), where one depends on each other's existence. In this case, masculinity and femininity are not seen as opposites, but each category is seen as an entity (Lucey, Olsvold, \& Aarseth, 2016).

As part of Muhammadiyah's gender ideology, the senior-junior concept (partnership) is still found. However, in practice the Muhammadiyah family is not absolutely principled in Senior junior partnership, but it is also influenced by Head complement relations patterns. This pattern of Head complement relationships confirms the role of husbands as breadwinners and heads of families, while women as managers and housekeepers (Fuad, 2004). The combination of senior-junior partnership and Head complement relations patterns can determine the ideal female figure according to Muhammadiyah's gender ideology, in which women can take part in the public domain (according to the Senior junior partnership relation pattern) without leaving their domestic obligations (according to Head complement relations pattern) (Syamsiyatun , 2007).

The combination of these concepts has actually existed since the time of Kyai Hajji Ahmad Dahlan, the founder of the Muhammadiyah Organization. He believes that women have the ability to regulate a strong economy (according to conditions when Muhammadiyah was established), the main producer of batik, and often families make their income. Ahmad Dahlan then thought to change the face of Islamic women from the practice of piety to the power of social change (C.-M. Hefner, 2016). They must have sufficient religious knowledge, and must develop cadres to encourage and shape intelligent young people from their family and friendship with the aim of forming pious leaders and teachers of Muslim women (Van Doorn-Harder, 2008).

Muhammadiyah's gender ideology, which was initiated by Kyai Hajji Ahmad Dahlan, has become the basis for gender progress in Indonesia, so that gender roles in Indonesia are not limited to ordination and sub-ordination (R. W. Hefner, 2017). 
Nevertheless, the culture that has been formed for a long time seems to prohibit the participation of women in the public sphere. However, along with the advancement of modern thoughts, the role of women in the public sphere is increasingly taken into account (Kloos \& Künkler, 2016). Indonesia as one of the countries, the largest Muslim adherents in the world, does not limit the role of women but prioritizes deliberation and consensus in making decisions.

\section{CONCLUSION}

The gender formation of foster children at Putri Aisyiyah orphanage in Tegal Municipality still perpetuates gender stereotypes when viewed from the perspective of Western feminist gender ideology (liberal / radical), considering that women still carry out their domestic roles even though they have been supported to take part in the public sphere. However, when viewed from the perspective of Muhammadiyah's gender ideology, the establishment of gender in orphanages has promoted women in accordance with the values and teachings of Islam. The formation of the gender role of foster children is adjusted to the ideal female figure according to the Muhammadiyah Gender Ideology, namely women who can take part in the public sphere without leaving an obligation in the domestic realm. To support the fostering of children in the public domain values that are closely related to masculinity such as independence, discipline, and leadership must be instilled. To support obligations in the domestic realm, femininity values and domestic skills taught to foster children must also be inculcated. Muhammadiyah's gender ideology emphasizes the balance between the role of women in the public sphere and the domestic realm.

\section{REFERENCES}

Al-anshori, M. Z. (2016). The Role Of Islam In Indonesia's Contemporary Foreign Policy. Victoria University of Wellington.

Aryanti, T. (2013). A claim to space: Debating female religious leadership in a muhammadiyah mosque in Indonesia. Muslim World, 103(3),
375-388. https://doi.org/10.1111/muwo.12020

Atmadja, N. B., Sendratari, L. P., \& Rai, I. W. (2015). Deconstructing Gender Stereotypes in Leak. Komunitas: International Journal of Indonesian Society and Culture, 7(1), 71. https://doi. org/10.15294/komunitas.v7i1.3597

Bogaerts, E. (2017). The installation of Prince Mangkubumi Performing Javanese history. Wacana, 17(3), 473. https://doi.org/10.17510/wacana. v17i3.456

Bowman, C. G. (2016). Recovering Socialism for Feminist Legal Theory in the 21 st Century. Connecticut Law Review, 49(1), 117-170.

Çatay, Z., \& Koloğlugil, D. (2017). Impact of a Support Group for the Caregivers At an Orphanage in Turkey. Infant Mental Health Journal, 38(2), 289-305. https://doi.org/10.1002/imhj.21629

Chu, Q., \& Gruhn, D. (2017). Moral Judgments and Social Stereotypes. Social Psychological and Personality Science. https://doi. org/10.1177/1948550617711226

Departemen Sosial Republik Indonesia. (2004). Pengertian Panti Asuhan. Jakarta : Depsos.

Dzuhayatin, Siti Ruhaini. (2015). Rezim Gender Muhammadiyah. Kontestasi Gender, Identitas, dan Eksistensi. Yoyakarta : Suka Press.

Efferin, S., Frisko, D., \& Hartanto, M. (2016). Management control system, leadership and gender ideology. Journal of Accounting in Emerging Economies, 6(4), 314-339. https://doi. org/10.1108/JAEE-10-2013-0052

Fakih, Mansour. (2010). Analisis Gender dan Transformasi Sosial. Yogyakarta: Pustaka Pelajar.

Fuad, M. (2004). Islam, modernity and Muhammadiyah's educational Programme. Inter-Asia Cultural Studies, 5(3), 400-414. https://doi. org/10.1080/1464937042000288697

Haines, E. L., Deaux, K., \& Lofaro, N. (2016). The Times They Are a-Changing ... or Are They Not? A Comparison of Gender Stereotypes, 1983-2014. Psychology of Women Quarterly, 40(3), 353363. https://doi.org/10.1177/0361684316634081

Hamed, S. K., \& Aziz, M. J. A. (2016). A question answering system on Holy Quran translation based on question expansion technique and Neural Network classification. Journal of Computer Science, 12(3), 169-177. https://doi. org/10.3844/jcssp.2016.169.177

Hefner, C.-M. (2016). Models of Achievement: Muslim Girls and Religious Authority in a Modernist Islamic Boarding School in Indonesia | ModelModel Prestasi: Perempuan Muslim dan Otoritas Agama di Madrasah Modernis di Indonesia. Asian Studies Review, 40(4), 1-19. https:// doi.org/10.108o/10357823.2016.1229266

Hefner, R. W. (2017). Sharia Law and Muslim Ethical Imaginaries in Modern Indonesia. In Sharia Dynamics (pp. 91-115). https://doi. org/10.1007/978-3-319-45692-8

Inpres Nomor 9 Tahun 2000 Tentang pengarusutamaan gender (PUG).

Izharuddin, A. (2017). Gender and Islam in Indonesian 
Cinema. https://doi.org/10.1007/978-981-102173-2

Kloos, D., \& Künkler, M. (2016). Studying Female Islamic Authority: From Top-Down to BottomUp Modes of Certification. Asian Studies Review, 40(4), 479-490. https://doi.org/10.108o/ 10357823.2016.1227300

Lucey, H., Olsvold, A., \& Aarseth, H. (2016). Working class fathers and daughters: Thinking about desire, identification, gender and education. Psychoanalysis, Culture \& Society, 21(2), 128146. https://doi.org/10.1057/pcs.2015.42

Marpinjun, S., \& Ramsey, P. G. (2017). Feminism ( s ) in Early Childhood. (S. Kylie, K. Alexander, \& S. Campbell, Eds.) (4th ed.). Australia.

Martam, I. (2016). Strategic social marketing to foster gender equality in Indonesia. Journal of Marketing Management, 32(11-12), 1174-1182. https:// doi.org/10.108o/0267257X.2016.1193989

Miftachul Huda, A.-Z., \& Kartanegara, M. (2015). Ethical Foundation of Character Education in Indonesia: Reflections on Integration between. Kolej Universiti Islam Antarbangsa (KUIS) Selangor, (April). https://doi.org/10.13140/ RG.2.1.5082.1605

Moleong, Lexy. 2009. Metodologi Penelitian Kualitatif. Bandung: Remaja Rosda Karya.

Murnen, S. K., Greenfield, C., Younger, A., \& Boyd, H. (2015). Boys Act and Girls Appear: A Content Analysis of Gender Stereotypes Associated with Characters in Children???s Popular Culture. Sex Roles, 1-14. https://doi.org/10.1007/ s11199-015-0558-x

Nasip, A. (2017). Imagologi dalam Perspektif Gender pada Organisasi Masyarakat Muhammadiyah ,. Education and Language International Conference, 37-48.

Qodir, Zuly. (2010). Muhammadiyah Studies : Reorientasi Gerakan dan Pemikiran Memasuki Abad Kedua.Yogyakarta : Kanisius.

Retsikas, K. (2016). The Other Side of the Gift: Soliciting in Java. Heidelberg Ethnology, 4(4).

Riany, Y. E., Meredith, P., \& Cuskelly, M. (2016). Understanding the influence of traditional cultural values on Indonesian parenting. Marriage $\mathcal{E}$
Family Review, 4929(March), 1-20. https://doi. org/10.1080/o1494929.2016.1157561

Shah, S. J. A. (2010). Re-thinking educational leadership: Exploring the impact of cultural and belief systems. International Journal of Leadership in Education, 13(1), 27-44. https://doi. org/10.1080/13603120903244879

Sherr, L., Roberts, K. J., \& Gandhi, N. (2017). Child violence experiences in institutionalised/orphanage care. Psychology, Health $\mathcal{E}$ Medicine, 22(Suppl 1), 31-57. https://doi.org/10.1080/1354 8506.2016.1271951

Suteja, Rani Sukma Ayu. (2013). Strategi Caregivers Dalam Mengkomunikasikan Gender (Gender Socialization) Pada Anak-Anak Lembaga Pengasuhan Sos Children'sVillage Lembang, Jawa Barat. Jurnal Commonline Departemen Komunikasi. Vol. 2.No. 2.

Syamsiyatun, S. (2007). A Daughter in the Indonesian Muhammadiyah: Nasyiatul Aisyiyah Negotiates a New Status and Image. Journal of Islamic Studies, 18(1), 69-94. https://doi.org/10.1093/ jis/etlo44

Tong, R. (2007). Feminist thought in transition: Never a dull moment. Social Science Journal, 44(1), 23-39. https://doi.org/10.1016/j.soscij.2006.12.003

Van Doorn-Harder, P. (2008). Controlling the Body: Muslim Feminists Debating Women's Rights in Indonesia. Religion Compass, 2(6), 1021-1043. https://doi.org/10.1111/j.1749-8171.2008.00105.x

Webforum Report. (2015). Global Gender Gap Report, World Economic Forum. [Forum Online]. Diakses dari http://reports.weforum.org/global-gender-gap-report-2015/rankings.

Wojnar, D. M., \& Swanson, K. M. (2007). Phenomenology: An Exploration. Journal of Holistic Nursing, 25(3), 172-18o. https://doi. org/10.1177/o898010106295172

Zumrodi. (2016). Pendidikan Sensistif Gender dalam Islam. Telaah Paradigmatis dalam Sejarah Intelektualisme Islam Indonesia. Jurnal PALASTREN, Vol.8, No. 2. Sekolah Tinggi Agama Islam Pati (STAIP). Jawa Tengah. 